\title{
The new era of interventional endoscopy
}

Interventional Gastroenterology is a rapidly expanding field at the cutting edge of innovation and novelty. New device technology coupled with improvements in endosonographic and high-definition imaging as well as the advent of carbon dioxide insufflation has led to a revolution in endoscopic therapy. The last decade has seen the emergence and widespread adoption of entirely new fields of endoscopy including therapeutic endoscopic ultrasound (T-EUS), third space endoscopy, and endobariatrics. In addition, new technology has allowed for major advancements in pancreaticobiliary management as well as Barretts Esophagus therapy.

Diseases of the pancreas, such as pancreatic lesions and pancreatitis, have traditionally been considered surgical diseases. However, recent trends have seen a major shift towards minimally invasive endoscopic therapies. Endoscopic drainage of pancreatic fluid collections with/without necrosectomy has become widely accepted as the superior first-line therapy. Pancreatic lesions that used to mandate surgical resection can now be successfully treated with EUS-guided radiofrequency ablation (EUS-RFA) in high-risk surgical patients. Pancreatic cysts can be better classified and risk-stratified based on new diagnostic/sampling technology available using EUS.

Similarly, many mucosal and submucosal lesions that used to mandate surgical resection can now be resected using endoscopic techniques. The advent of submucosal tunneling between the layers of the gastrointestinal (GI) tract has allowed for the emergence of per-oral endoscopic myotomy (POEM) and submucosal tunneling endoscopic resection (STER). Better closure techniques such as endoscopic suturing and over-the-scope clips have facilitated the emergence of endoscopic submucosal dissection (ESD) and endoscopic full-thickness resection (EFTR), often negating the need for more invasive therapies with high morbidity and even mortality.

The emergence of therapeutic EUS has allowed for not only avoidance of surgery in high-risk patients but also avoidance of long-term percutaneous drainage catheters which come with a high price in terms of quality of life and morbidity. The emergence of endobariatrics has filled a treatment gap for the obesity epidemic currently plaguing the world and only expected to worsen with time. Improvements in device technology have advanced the endoscopic management of pancreaticobiliary diseases such as indeterminate biliary strictures and malignant biliary obstruction as well as esophageal diseases such as Barretts Esophagus.

The new era of endoscopy is filled with innovation and advancement at an unprecedented rate and with no end in sight. Overall, it is an exciting time to be an interventional gastroenterologist!

\section{Acknowledgments}

Funding: None.

\section{Footnote}

Provenance and Peer Review: This article was commissioned by the editorial office, Translational Gastroenterology and Hepatology for the series "Innovation in Endoscopy". The article did not undergo external peer review.

Conflicts of Interest: The author has completed the ICMJE uniform disclosure form (available at https://tgh.amegroups.com/ article/view/10.21037/tgh-21-14/coif). The series "Innovation in Endoscopy" was commissioned by the editorial office without any funding or sponsorship. AT served as the unpaid Guest Editor of the series and serves as an unpaid editorial board member of Translational Gastroenterology and Hepatology from April 2019 to March 2023. AT reports that she serves as an consultant for Boston Scientific and EndoGastric Solutions, outside the submitted work. The author has no other conflicts of interest to declare.

Ethical Statement: The author is accountable for all aspects of the work in ensuring that questions related to the accuracy or integrity of any part of the work are appropriately investigated and resolved. 
Open Access Statement: This is an Open Access article distributed in accordance with the Creative Commons AttributionNonCommercial-NoDerivs 4.0 International License (CC BY-NC-ND 4.0), which permits the non-commercial replication and distribution of the article with the strict proviso that no changes or edits are made and the original work is properly cited (including links to both the formal publication through the relevant DOI and the license). See: https://creativecommons.org/ licenses/by-nc-nd/4.0/.

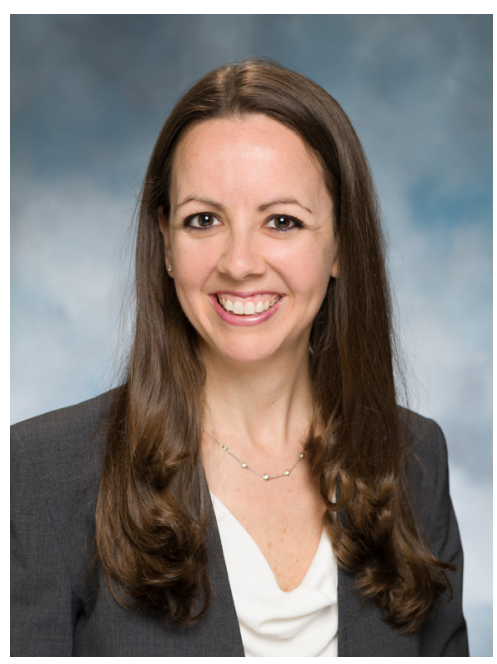

Amy Tyberg

Amy Tyberg, MD, FASGE, FACG

Associate Professor of Medicine, Vice Chair of Clinical Affairs, Director of Therapeutic Endoscopic Ultrasound, Associate Director of Endoscopy, Department of Medicine, Division of Gastroenterology, Rutgers Robert Wood Fohnson Medical School, New Brunswick,

Nf, USA. (Email: Amy.Tyberg@gmail.com)

Received: 09 October 2020; Accepted: 29 January 2021; Published: 25 April 2022.

doi: $10.21037 /$ tgh-21-14

View this article at: http://dx.doi.org/10.21037/tgh-21-14

doi: $10.21037 / \operatorname{tgh}-21-14$

Cite this article as: Tyberg A. The new era of interventional endoscopy. Transl Gastroenterol Hepatol 2022;7:14. 